\title{
Abrogation of contaminating RNA activity in HIV- 1 Gag VLPs
}

Ziyaad Valley-Omar ${ }^{1,2}$, Ann E Meyers ${ }^{1 *}$, Enid G Shephard ${ }^{2,3,4}$, Anna-Lise Williamson ${ }^{2,5}$ and Edward P Rybicki,2

\begin{abstract}
Background: HIV-1 Gag virus like particles (VLPs) used as candidate vaccines are regarded as inert particles as they contain no replicative nucleic acid, although they do encapsidate cellular RNAs. During HIV-1 Gag VLP production in baculovirus-based expression systems, VLPs incorporate the baculovirus Gp64 envelope glycoprotein, which facilitates their entry into mammalian cells. This suggests that HIV-1 Gag VLPs produced using this system facilitate uptake and subsequent expression of encapsidated RNA in mammalian cells - an unfavourable characteristic for a vaccine.

Methods: HIV-1 Gag VLPs encapsidating reporter chloramphenicol acetyl transferase (CAT) RNA, were made in insect cells using the baculovirus expression system. The presence of Gp64 on the VLPs was verified by western blotting and RT-PCR used to detect and quantitate encapsidated CAT RNA. VLP samples were heated to inactivate CAT RNA. Unheated and heated VLPs incubated with selected mammalian cell lines and cell lysates tested for the presence of CAT protein by ELISA. Mice were inoculated with heated and unheated VLPs using a DNA prime VLP boost regimen.
\end{abstract}

Results: HIV-1 Gag VLPs produced had significantly high levels of Gp64 ( 1650 Gp64 molecules/NLP) on their surfaces. The amount of encapsidated CAT RNA/ $\mu \mathrm{g}$ Gag VLPs ranged between 0.1 to $7 \mathrm{ng}$. CAT protein was detected in 3 of the 4 mammalian cell lines incubated with VLPs. Incubation with heated VLPs resulted in BHK-21 and HeLa cell lysates showing reduced CAT protein levels compared with unheated VLPs and HEK-293 cells. Mice inoculated with a DNA prime VLP boost regimen developed Gag CD8 and CD4 T cell responses to GagCAT VLPs which also boosted a primary DNA response. Heating VLPs did not abrogate these immune responses but enhanced the Gag CD4 T cell responses by two-fold.

Conclusions: Baculovirus-produced HIV-1 Gag VLPs encapsidating CAT RNA were taken up by selected mammalian cell lines. The presence of CAT protein indicates that encapsidated RNA was expressed in the mammalian cells. Heat-treatment of the VLPS altered the ability of protein to be expressed in some cell lines tested but did not affect the ability of the VLPs to stimulate an immune response when inoculated into mice.

\section{Background}

Inert virus-like particles (VLPs) made from virus structural protein(s) are an ideal substitute for live, attenuated and peptide-based virus vaccines, as they present epitopes in an immunologically relevant context and lack any replicative nucleic acid. Several VLP-based vaccines have been developed against human viruses, such as the recently-released human papillomavirus (HPV) vaccines, and the well-established hepatitis B virus

\footnotetext{
* Correspondence: ann.meyers@uct.ac.za

'Department of Molecular and Cell Biology, Faculty of Science, University of

Cape Town, University Ave, Rondebosch 7701, South Africa

Full list of author information is available at the end of the article
}

(HBV) vaccines [1-3]. Gag polyproteins of human and simian immunodeficiency viruses (HIV and SIV) produced in various expression systems (bacterial, yeast, insect, mammalian and plant cells) also assemble into VLPs that bud through plasma membranes to produce enveloped particles, which strongly resemble immature virions. These VLPs have been shown to be potent stimulators of both cellular and humoral immune responses in animal models and therefore are potentially excellent vaccine candidates [4-11].

During virion assembly, HIV Gag encapsidates two copies of the viral genomic RNA displaying a HIV packaging signal called the $\psi$-site [12-17]. The

\section{Biomed Central}


incorporation of specific viral RNA, though, is not a prerequisite for virion assembly and release [18-23]. In the absence of $\psi$-site-containing viral RNA, assembling viral particles still encapsidate high levels of host cell derived RNA [13,21,21,22,24]. This non-specific RNA encapsidation is mediated by RNA binding to basic residues distributed throughout various domains of Gag [18,19,23,25-28]. Gag proteins with specific mutations in these domains were shown to be unable to package RNA, and consequently unable to assemble into particles $[18,23]$. RNA has thus been shown to play a key structural role in virus particle assembly by serving as a scaffold upon which multiple Gag molecules can assemble [19,23,29-33]. As a result, HIV Gag VLPs produced in the aforementioned expression systems may thus contain significant levels of encapsidated host cellular RNA.

The primary mode of HIV entry into cells was assumed to be by Gp120/Gp41-and CD4+ host cell CD4 + CCR5/CXCR4 receptor-mediated plasma membrane fusion [34,35]. More recent studies have documented viral entry into cells mainly via a Gp120/Gp41-independent endocytic pathway, with HIV particles shown to be present within acidified endocytic vesicles destined for degradation [36-41]. At least 50-90\% of viral material has been shown to enter cells by this Gp120/Gp41-independent endosomal pathway when viral particles contain functional Gp120/Gp41 [36-38,41], which suggests that the endocytic/degradative pathway is a major entry route. HIV virions may also be internalised by macropinocytosis in a receptor and $\mathrm{pH}$-independent process $[39,41]$; however, only Gp120/Gp41-displaying virions were shown to access the cytosol, presumably by engaging specific receptors on the internal surface of the macropinosome/endosome. The general consensus of HIV cellular entry studies is that, irrespective of the path of entry into the target cell, successful HIV infection is dependent on receptor/co-receptor interactions at the cell surface or within vesicles.

HIV-1 Gag VLPs are often produced in baculovirusbased insect cell expression systems, which provide an ideal eukaryotic environment for the production of biologically active recombinant proteins as they enable post-translational modifications such as proper protein folding, disulphide bond formation, oligomerisation and proteolytic cleavage [42]. VLPs that bud from insect cells accordingly become enveloped with the insect host cell membrane, which contains abundant baculovirus Gp64 envelope glycoprotein. These VLPs are said to be pseudotyped with Gp64. Gp64 is one of the most abundant proteins comprising the baculovirus virion, and is crucial for infectivity and functionality of the baculovirus expression system [43]. Gp64 mediates baculovirus entry into cells via an influenza-like, clathrin-mediated, low pH-dependent endocytic pathway, where viral and endosomal membrane fusion occurs subsequent to endosomal acidification [44-53].

Gp64-mediated baculovirus uptake is not limited to insect cells. Several studies have demonstrated the ability of recombinant baculoviruses to enter host mammalian cells, and subsequent gene expression to occur within these cells. Their uptake has been demonstrated in vivo in mouse nasal epithelia, mouse skeletal muscle cells, rabbit endothelial cells, and in vitro in various mammalian cell lines including HeLa, Vero, BHK-21, 293 T-cells, rat hepatocytes and human hemocytes and hepatocytes [54-61]. Lentiviral (HIV/MLV) vectors pseudotyped with Gp64 have been shown to be taken up by mammalian cell lines with the same target cell range as that observed for recombinant baculoviruses, which include cells of hepatic origin, 293 T-cells, HeLa and HuH-7 human cell lines, while haematopoietic cells were not [62-64]. In addition, Schauber et al [63] and Sinn et al [64] have demonstrated the efficient gene transfer potential of Gp64 pseudotyped lentiviral (HIV/ FIV) vectors in vivo.

While endosomal degradation of non-pseudotyped (Gp160) VLPs subsequent to cellular entry should effectively prevent the transmission and expression of VLPcontained RNAs, the presence of baculovirus Gp64 on the surface of Gag VLPs could enable expression of these RNAs within eventual mammalian vaccine recipients. The potential delivery and expression of insect cell-derived nucleic acids by VLPs within a vaccinated individual is regarded as a problematic trait by vaccine regulatory bodies such as the United States Food and Drug Administration (FDA). The FDA specifically requires vaccine developers to show that VLPs do not encapsidate "specific" nucleic acid sequences from the expression system, and especially those encoding VLPs components.

In this study we tested the ability of insect cell-produced HIV Gag VLPs to function as a vector for RNA uptake in several mammalian cell lines. Also, as the amount of Gp64 on the surface of insect cell-produced HIV-1 Gag VLPs has not been determined, this study initially estimated the relative levels of Gp64 per VLP. This study is the first, to our knowledge, to analyse the potential transfer and successful expression of encapsidated reporter CAT RNAs from non-replicating Gag VLPs in mammalian cell lines: previous studies have all been conducted on more complex live lentivirus models that carried reporter genes as part of the replicative viral genome $[62,63]$. VLPs were heated in an attempt to inactivate any RNA encapsidated by the VLPs and the CAT expression in mammalian cells after uptake was investigated. In addition, we compared the ability of heat-treated VLPs and unheated VLPs to stimulate an immune response in mice. GagCAT VLPs were 
immunogenic in mice, and heating of the VLPs appears to enhance the immunogenicity of these VLPs especially when used as a booster vaccine after a prime with a matching DNA vaccine.

\section{Methods}

\section{Baculovirus-produced GagCATVLPs}

A Pr55 gag gene encoding the Gag sequence with a myristoylation signal, derived from the $\mathrm{Du}_{422}$ clinical isolate $[65,66]$ was human codon-optimised (hmGag; Operon Technologies (USA)) and cloned into the pFastBac $^{\text {TM }}$ Dual (pFBD) baculovirus insect cell expression vector (Invitrogen) under the p10 promoter to produce the pFBDGag construct. The pFBDGagCAT construct was generated by cloning a chloramphenicol acetyltransferase (CAT) reporter gene, derived from the pcDNA3.1/Zeo/CAT cloning vector (Invitrogen), into the gag-containing $\mathrm{pFastBac}{ }^{\mathrm{TM}}$ Dual construct under the polyhedrin $(\mathrm{PH})$ promoter (Figure 1a). Baculovirus produced pFBDGagCAT and control pFBDGag bacmids were generated in a Spodoptera frugiperda-derived Sf21 cell line (Invitrogen) [7,42,67-70]. Briefly, the $S f 21$ cells were maintained as a monolayer at $27^{\circ} \mathrm{C}$ in $\mathrm{TC}-100$ insect medium (Sigma) supplemented with $10 \%(\mathrm{v} / \mathrm{v})$ foetal bovine serum (FBS), $50 \mu \mathrm{g} / \mathrm{ml}$ neomycin, $69.2 \mu \mathrm{g} /$ $\mathrm{ml}$ penicillin $\mathrm{G}$ and $100 \mu \mathrm{g} / \mathrm{ml}$ streptomycin. Sf21 cells $\left(1 \times 10^{6}\right.$ cells $\left./ \mathrm{ml}\right)$ were infected with the recombinant pFBDGagCAT and control pFBDGag baculovirus at a multiplicity of infection (MOI) of 2-10, and VLPs were harvested from $100 \mathrm{ml}$ of culture supernatant $72 \mathrm{~h}$ post infection by means of cross-flow filtration using a crossflow filter unit (MidGee ${ }^{\mathrm{TM}}$, GE Healthcare) with a 300 $\mathrm{kDa}$ cut-off filter cartridge according to the manufacturer's protocol. VLPs were pelleted by centrifugation at $83,000 \times g$ and resuspended in $300 \mu \mathrm{l}$ of $1 \times$ sterile Dulbecco's phosphate buffered saline (PBS, Sigma ${ }^{\mathbb{R}}$ ) and incubated with $7.5 \mathrm{u}$ RNase A and $1.33 \mathrm{u}$ RNase T1 for $2 \mathrm{~h}$ at $37^{\circ} \mathrm{C}$ [23] to remove any RNA in the surrounding medium. VLPs were re-purified by centrifugation through a $20 \%$ sucrose cushion at $83,000 \times g$ and resuspended in PBS containing 15\% trehalose to maintain VLP stability.

\section{Electron microscopy of GagCAT VLPs}

GagCAT VLPs were visualized using a LEO 912 transmission electron microscope after adsorption onto 200 mesh carbon-coated copper grids stained with $2 \%$ uranyl acetate.

\section{Quantification of Gag and Gp64 of GagCAT VLPs}

The purity of VLPs were assessed and Gag concentration of the GagCAT VLP preparation was measured by electrophoresis of purified VLPs through a $10 \%$ denaturing SDS polyacrylamide gel and western blotting [68].
To quantitate the Gag concentration a serial dilution of an HIV-1 p17/24 C clade protein standard (ARP695.2, FIT Biotech, Programme EVA, centre for AIDS reagents, NIBSC) was included on the gel. Membranes were probed with a 1/5000 dilution of anti-p24 polyclonal rabbit antiserum (ARP432, NISBC Centralised Facility for AIDS reagents, MRC, UK) and a 1/5000 dilution of an anti-rabbit alkaline phosphatase-conjugated secondary antibody (Sigma-Aldrich). Gag protein was visualised using 5-bromo-4-chloro-3-indolyl phosphate/nitro blue tetrazolium (BCIP/NBT) (Roche). The Gag concentration of the GagCAT VLP preparation was estimated by densitometry which compared the collective density of all Gag bands with the density of the Gag bands for the standard using gel imaging software (Gene Genius Bio, Syngene). The VLPs were resuspended at $1 \mu \mathrm{g} \mathrm{Gag} / \mu \mathrm{l}$ PBS containing $15 \%$ trehalose and stored at $-70^{\circ} \mathrm{C}$. The Gp64 content of the GagCAT VLP preparation was visualized by probing the membrane with a $1 / 5000$ dilution of a purified mouse anti-baculovirus Gp64 envelope glycoprotein antibody (Clone: AcV5; eBioscience) and anti-mouse alkaline phosphatase-conjugated secondary antibody (Sigma-Aldrich) and developed with BCIP/ NBT. Gp64 was quantitated from Coomassie-stained gels using serial dilutions of a BSA standard and densitometry as described for quantification of Gag protein above and variance was determined using Prism 5 (GraphPad).

\section{Inactivation of VLP RNA}

For use in cell-uptake experiments, GagCAT VLP samples were heated at $62^{\circ} \mathrm{C}$ for 20 minutes (called hVLPs) based on the method used for heat-inactivating live HIV particles [71].

\section{Detection and quantitation of CAT RNA}

RT-PCR (Access RT-PCR System, Promega) of GagCAT VLPs and these VLPs after heat treatment (hVLPs) contained $5 \mu \mathrm{l}$ of the VLP preparation (equivalent to $5 \mu \mathrm{g}$ Gag protein) in $100 \mu \mathrm{l}$ and $1 \mathrm{mM} \mathrm{MgCl} \mathrm{Mith}_{2}$ wi pmol of the primers designed to yield a 350 bp product. The forward and reverse primer sequences used were 5' GCAATGAAAGACGGTGAGC 3' and 5' ATGAACCTGAATCGCCAGC 3', respectively. In vitro-transcribed CAT RNA was used as a positive control (Ribomax ${ }^{\mathrm{TM}}$ Large Scale RNA Production System - T7 kit (Promega). The cycle profile was as follows: $45^{\circ} \mathrm{C}, 45 \mathrm{~min} ; 94^{\circ} \mathrm{C}, 2$ min; 25 cycles of $94^{\circ} \mathrm{C}, 30 \mathrm{sec} ; 57^{\circ} \mathrm{C}, 30 \mathrm{sec} ; 72^{\circ} \mathrm{C}, 1 \mathrm{~min}$.

RNA was extracted from GagCAT VLPs after heat treatment using the RTP Virus DNA-RNA Isolation Kit (Invitek). Each RNA extraction was carried out using 5 $\mu \mathrm{l}$ of the VLP preparation (equivalent to $5 \mu \mathrm{g}$ Gag protein) and the RNA was eluted in $50 \mu \mathrm{l}$ of extraction kit elution buffer after which $10 \mu \mathrm{l}$ was used for real-time 
a)

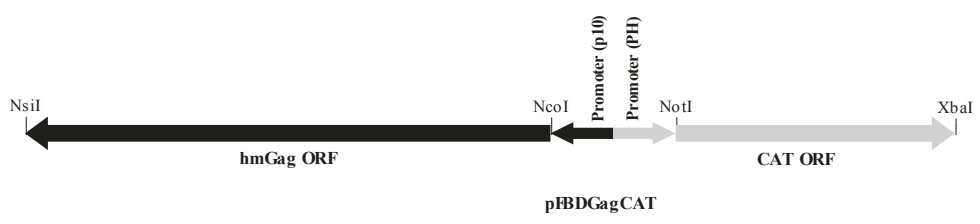

b)

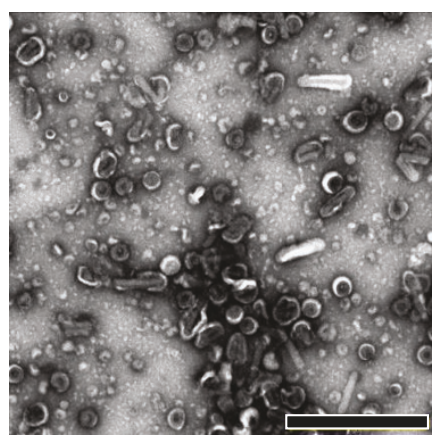

d)

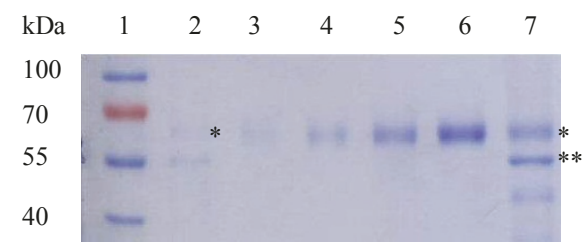

e)

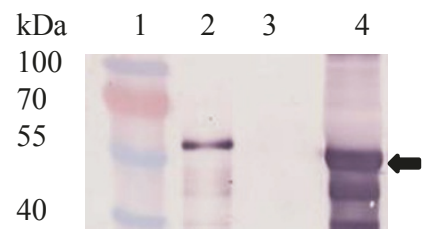

c)

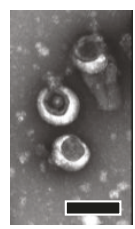

f)

40

g)
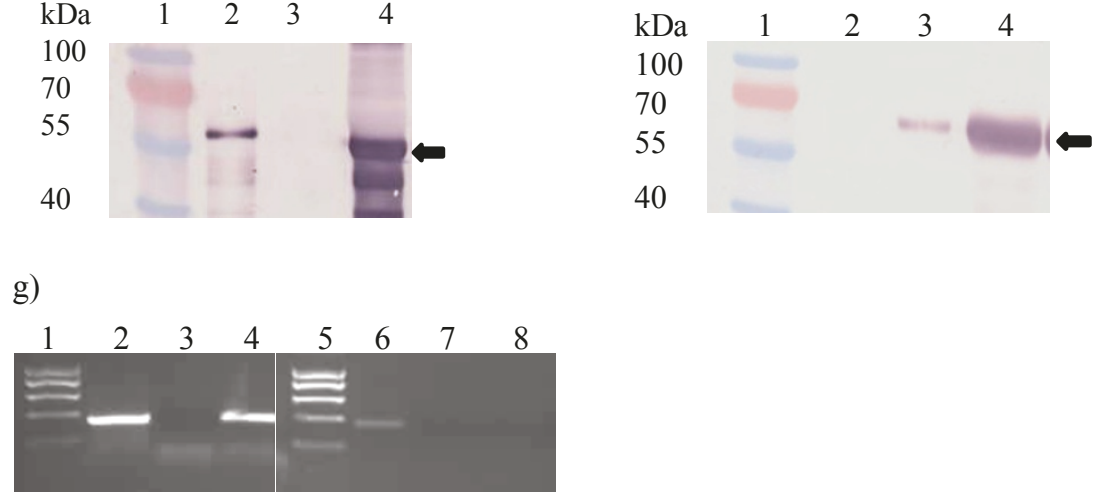

Figure 1 VLP isolation and quantification. a) Schematic diagram of pFBDGagCAT showing the Gag and CAT open reading frames under the control of the p10 and pH promoters, respectively. (b) Transmission electron micrograph of purified GagCAT VLPs. Arrows indicate typical doughnut-shaped VLPS (120 - $150 \mathrm{~nm}$ in diameter). Scale bar $=1000 \mathrm{~nm}$. (c) Transmission electron micrographs of Gag VLPs after heating at $62^{\circ}$ C for 20 minutes. Scale bar $=200 \mathrm{~nm}$. (d) Coomassie-stained 10\% SDS polyacrylamide gel used to densitometrically quantify Gp64 on in Gag VLP preparations. Lane 2 contains the Gp64 positive control (*), while lanes 3-6 contain dilutions of BSA at 100, 200, 500 and 1000 ng, respectively. Lane 7 contains Gag VLPs containing 1000 ng of Gag, showing gp64 (*) and Gag ${ }^{\operatorname{Pr5} 5}\left({ }^{* *}\right)$. (e) and ( $($ ) Comparative western blots of purified VLP extracts probed with anti-Gag primary antibody (e) and anti-Gp64 primary antibody (f): Lane 2 - HIV-1 p17/p24 C clade protein standard (ARP695.2); Lane 3 - Gp64 positive control; Lane 4 - Purified GagCAT VLPs. Black arrows indicate the position of the 55 kDa HIV Gag (e) and 64 kDa VSV Gp64 (f) proteins, respectively. (g) 1\% agarose gel showing DNA fragments generated by RT-PCR (lanes 2-4) and PCR (lanes 6-8) of GagCAT VLPs using CAT-specific primers. Lane 1 - molecular weight marker; Lanes 2 and 6 - 350bp positive control fragments generated using in vitro-transcribed CAT RNA and CAT DNA for RT-PCR and PCR, respectively; Lanes 3 and 7 - result of negative control experiments generated by RT-PCR and PCR of Gag VLP RNA extracts, respectively; Lanes 4 and 8 - results of RT-PCR and PCR using GagCAT VLP RNA extracts, respectively. 
RT-PCR. These reactions were performed using a SensiMix One-Step real-time RT-PCR kit (Quantace) and a Rotor-Gene RG-3000A real-time PCR machine (Corbett Research). Reactions $(25 \mu \mathrm{l})$ contained in vitro-transcribed CAT RNA as a standard or $10 \mu \mathrm{l}$ of the RNA extracted from the GagCAT VLP preparation, $50 \mathrm{mM}$ $\mathrm{MgCl}_{2}$ and $50 \mathrm{pmol}$ of forward and reverse primers to amplify a 150 bp DNA fragment. The forward and reverse primer sequences used were 5' AGATGTGGCGTGTTACGGT 3' and 5' ATGAACCTGAATCGCCAGC 3', respectively. The reaction profile used was as follows: $49^{\circ} \mathrm{C}, 45 \mathrm{~min} ; 95^{\circ} \mathrm{C}, 10 \mathrm{~min} ; 30$ cycles of $95^{\circ} \mathrm{C}, 15 \mathrm{sec}, 57^{\circ} \mathrm{C}, 15 \mathrm{sec}$ and $72^{\circ} \mathrm{C}, 15 \mathrm{sec}$. All real-time RT-PCR data was analysed using the Rotorgene 6, Version 6.0 (Build 27) software (Corbett Research).

\section{GagCAT VLP uptake by mammalian cell lines}

Murine macrophages (RAW 264.7), baby hamster kidney cells (BHK-21), human embryonic kidney cells (HEK 293) and HeLa cells were maintained as continuous cultures at $37^{\circ} \mathrm{C}$ in $5 \% \mathrm{CO}_{2}$. RAW 264.7 cells were cultured in RPMI (RPMI 1640+GlutaMAX ${ }^{\mathrm{TM}}-1$, Gibco ${ }^{\circledR}$ ) and BHK-21 cells, HEK 293 and HeLa cells were cultured in DMEM (DMEM+GlutaMAX ${ }^{\mathrm{TM}}-1$, Gibco $\left.^{\circledR}\right)$. These media were supplemented with $10 \%(\mathrm{v} / \mathrm{v})$ foetal calf serum (Gibco), 1\% penicillin G/streptomycin and 1\% Fungin (supplemented culture medium). Twenty four hours prior to GagCAT VLP uptake the RAW 264.7, BHK-21 and HeLa cell cultures were seeded in 6-well plates (Nunc ${ }^{\mathrm{TM}}$ ) in $2 \mathrm{ml}$ supplemented culture medium at a concentration of $0.5 \times 10^{5}$ cells $/ \mathrm{ml}$ per well, while HEK 293 cells were seeded in 6 -well plates at $0.2 \times 10^{5}$ cells/ ml supplemented culture medium per well. Cells were washed twice with $2 \mathrm{ml}$ PBS prior to the addition of GagCAT VLPs in a volume of $1 \mathrm{ml}$ unsupplemented culture medium and incubated at $37^{\circ} \mathrm{C}$ for $2 \mathrm{~h}$, which was then replaced with $2 \mathrm{ml}$ of supplemented culture medium and incubated for $24 \mathrm{~h}$ at $37^{\circ} \mathrm{C}$ after which cell lysates were prepared and CAT protein content analysed by ELISA (Roche CAT ELISA kit). Each cell-type transfection was carried out with the same VLP and heated VLP preparations and the entire experiment was carried out in triplicate. ELISA plates were analysed using a PowerWave $^{\mathrm{TM}}$ XS ELISA plate reader $\left(\right.$ BioTek $\left.^{\circledR}\right)$ and results analysed using the $\mathrm{KCL}^{\mathrm{TM}}$ (version 3.4 ) program $\left(\right.$ BioTek $\left.^{\circledR}\right)$. Mean values of triplicate assays for a cell lysate did not vary by more than $5 \%$. Data is presented as mean responses for 6 replicate uptake experiments.

\section{Immune responses in mice}

Female BALB/c mice (8-10 weeks old) were used to compare immune responses of GagCAT VLPs and heated GagCAT VLPs (hGagCAT VLPs) when given alone. The ability of these VLPs to boost a primary response induced by a matched HIV-1 subtype C DNA vaccine, pTHGagC [7] was also determined. All mouse procedures were approved by the UCT Animal Ethics Committee, (AEC no. 006-007). Plasmid (100 $\mu \mathrm{g}$ DNA) and VLPs (400 ng Gag protein) in PBS were given as intramuscular injections in a final volume of $100 \mu \mathrm{l}$ with $50 \mu \mathrm{l}$ injected into each hind leg muscle. Spleens were collected from groups of mice on day 40 after a prime inoculation on day 0 with pTHGagC and a boost with either GagCAT VLPs, hGagCAT VLPs or pTHGagC on day 28. Groups of mice were also left unvaccinated and then on day 28 vaccinated with GagCAT VLPs or hGagCAT VLPs and spleens collected on day 40 to determine responses to these VLPs only [68]. Splenocyte suspensions were prepared from spleens pooled from 5 mice per group and red blood cells (RBC) were lysed (RBC lysing solution, Sigma). IFN- $\gamma$ and IL-2 ELISPOT assays (BD Pharmingen) were performed according to manufacturer's instructions to assess the frequency of Gagspecific IFN- $\gamma$ and IL-2 secreting CD8 and CD4 T cells. Triplicate wells contained 500000 splenocytes/well in a final volume of $200 \mu \mathrm{l} \mathrm{R} 10$ medium (RPMI 1640+GlutaMAX $^{\mathrm{TM}_{-}} 1$ with $20 \mathrm{mM}$ HEPES, $10 \%$ heat inactivated FCS, $15 \mathrm{mM} \beta$-mercaptoethanol, $1 \%$ penicillin G/streptomycin) only to determine background responses or in this medium with the peptides (> 95\% pure; Bachem, Switzerland) AMQMLKDTI (Gag CD8) or NPPIPVGRIYKRWIILGLNK (Gag CD4(13) peptide) or FRDYVDRFFKTLRAEQATQE (Gag CD4(17) peptide) $[72,73]$. Spots were detected using Nova Red substrate (Vector Labs) then scanned and counted using a CTL Analyzer (Cellular Technology, OH, USA) with Immunospot Version 3.2 software. The mean number of spots from triplicate wells \pm SD (standard deviation) was calculated and mean background spots were subtracted then adjusted to spot forming units (sfu) per $10^{6}$ splenocytes \pm SD.

\section{Results and discussion}

\section{Characteristics of baculovirus-produced GagCAT VLPs}

Transfection of $S f 21$ insect cells with pFBDGagCAT yielded VLPs that could be harvested by cross-flow filtration from insect cell culture supernatant. Transmission electron microscopy of the purified VLPs showed numerous doughnut-shaped particles with diameters ranging in size from 120 to $150 \mathrm{~nm}$ (Figure 1b). A few baculovirus particles were occasionally observed in samples of the VLP preparations viewed under the electron microscope, but not in all fields of view. Although the ratio of baculovirus particles to VLPs was not calculated, it was considered too small to interfere with the estimated calculation of Gp64 protein per $\mu \mathrm{g}$ of Gag protein by much. A Coomassie-stained gel of GagCAT VLP 
preparations showed a dominant $55 \mathrm{kDa}$ band of HIV-1 Gag protein (Figure 1d - lane $7^{* *}$ ). The higher band is thought to be the $64 \mathrm{kDa}$ gp64 protein and the lower band is a p41 HIV-1 Gag breakdown product which has been observed in previous work in this laboratory [67]. Western blotting of GagCAT VLPs using an anti-Gag antibody confirmed the presence of the $55 \mathrm{kDa} \mathrm{HIV}-1$ Gag protein (Figure 1e - lane 4). A western blot of GagCAT VLPs using an anti-Gp64 antibody showed a band of $64 \mathrm{kDa}$ in size (Figure 1f - lane 4) which confirmed the association of this protein with the purified GagCAT VLP preparations. As there was no quantified Gp64 standard available for western blot or ELISA quantitation, the relative amount of Gp64 incorporated into the GagCAT VLPs per microgram of VLPs Gag protein was determined densitometrically using quantitated amounts of BSA on a Coomassie-stained gel (Figure 1d - lanes 3 to 6). The average Gp64 concentration was calculated to be $383 \pm 86 \mathrm{ng}$ Gp64/ug of Gag after analysis of four separate VLP purifications analysed in triplicate.

\section{CAT RNA in GagCAT VLPs}

To determine whether CAT RNA was encapsidated in the purified GagCAT VLPs, RT-PCR using CAT-specific primers was carried out on purified GagCAT VLP RNA. The presence of CAT RNA was shown by successful amplification of a 350 bp DNA fragment (Figure 1g lane 4), corresponding to the positive control, which was generated using in vitro-transcribed CAT RNA (Figure $1 \mathrm{~g}$ - lane 2).

No product was amplified from RNA extracted from Gag VLPs (Figure 1e - lane 3 and 7) which were produced after transfection of $S f 21$ insect cells with a construct lacking CAT (pFBDGag). To exclude the possibility that DNA fragments could have resulted from amplification of contaminating CAT DNA co-purified from the insect-cell preparation, GagCAT VLPs were subjected to PCR using CAT-specific primers, which failed to amplify any product (Figure $1 \mathrm{~g}$ - lane 8 ). A 350 bp DNA fragment was observed from amplification of CAT DNA (lane 6) and no fragment was observed from amplification of Gag VLP RNA (lane 7), as expected.

The amount of CAT RNA encapsidated by $1 \mu \mathrm{g}$ of Gag VLPs was quantitated by real-time RT-PCR using in vitro-transcribed RNA as a standard. CAT RNA quantitation of nine individual GagCAT VLP preparations showed that the amount of encapsidated CAT RNA/ $\mu$ g Gag VLPs varied between individual VLP preparations (0.1 - 7 ng CAT RNA/ $\mu$ g Gag VLPs) (data not shown).

\section{Expression of encapsidated CAT RNA in mammalian cell lines}

To test whether CAT RNA could indeed be transcribed and translated into protein in mammalian cells, we determined the presence of CAT protein in BHK-21 cells after transfection with in vitro-transcribed CAT RNA. CAT RNA transcription and translation was confirmed by the detection of CAT in cell lysates (data not shown). To investigate whether CAT RNA can be expressed in mammalian cells after uptake of GagCAT VLPs, VLPs containing $10 \mathrm{ng}$ of CAT RNA were added to 4 different mammalian cell types and CAT protein expression levels in cell lysates quantified by CAT ELISA after 24 hours. The cell lines were selected on the basis of availability in the laboratory, as well as the fact that at least 3 of them are known to facilitate entry of Gp64-pseudotyped viral particles by means of a Gp64 receptor that is present on their outer cell wall $[56,58,74]$. Cell lysates prepared from BHK-21, HEK 293 and HeLa cells contained CAT protein (Figure 2). In contrast, lysates of the murine macrophage cell line (RAW 264.7), a hematopoietic cell line, known to be non-receptive to baculovirus Gp64 mediated transfection [57] did not contain CAT protein after incubation with the GagCAT VLPs (data not shown). CAT protein expression levels between the 3 different cell lines ranged from $0.7-0.86 \mathrm{ng} / \mathrm{ml}$ of CAT, when transfected with VLPs containing a total $10 \mathrm{ng}$ of CAT RNA respectively (Figure 2).

\section{Effect of heat treatment on expression of encapsidated CAT RNA in mammalian cell lines}

The cellular uptake and subsequent transcription of GagCAT RNA encapsidated by the VLPs has implications for their use as a vaccine. It is important to limit transmission and expression of RNA encapsidated by VLPs to ensure no production of a protein that may cause ill effects when VLPs are administered as a vaccine. We tested whether heating the VLPs (using a

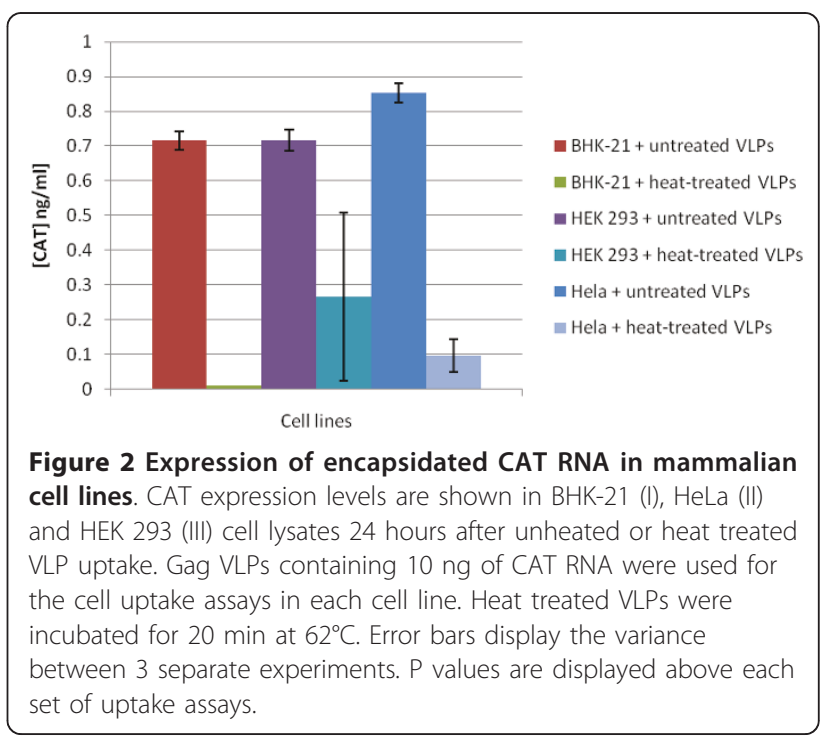


heating method based on that used to inactivate HIV particles [71,75]) would impact on the GagCAT transcription and translation after VLP uptake in certain mammalian cells. Gag VLPs carrying $10 \mathrm{ng}$ of CAT RNA were incubated at $62^{\circ} \mathrm{C}$ for 20 minutes prior to incubation with BHK-21, HEK 293 and HeLa cells. Twenty four hours following cell uptake, cell lysates were analysed for CAT expression by CAT ELISA (Figure 2). Lysates of BHK-21 and HeLa cells after uptake of heat treated VLPs contained significantly reduced ( $p$ $<0.0001)$ CAT protein levels compared to lysates from cells that had been incubated with unheated VLPs. On the contrary, expression of CAT in HEK-293 cells after uptake of heat treated VLPs was marginally different from that after uptake by unheated VLPs (Figure 2). Heat-treated VLPs were not physically or structurally damaged (Figure 1c). TEM proved them to be intact doughnut-shaped particles, similar to non-heated VLPs as shown in Figure 1b.

\section{GagCAT VLPs before and after heat treatment are immunogenic in mice}

Since the aim of this work is to develop a vaccine that does not transmit foreign RNAs but will maintain an immune response to Gag, immune responses to single vaccinations of GagCAT VLPs and heat treated GagCAT VLPs were compared in BALB/c mice. In addition, the effect of heating GagCAT VLPs on their ability to boost a DNA vaccine prime (pTHGagC) was compared to that of two vaccinations of pTHGagC. T cell responses to a Gag CD8 peptide and two Gag CD4 peptides (Gag CD4 (13) and Gag CD4 (17)) were measured using IFN- $\gamma$ and IL-2 ELISPOT assays as the measure of the immune response (Figure 3a). A VLP only vaccination induced a cumulative response to the Gag CD4(13) and Gag CD4(17) peptides of $192 \mathrm{sfu} / 10^{6}$ splenocytes in the IFN- $\gamma$ ELISPOT assay while a heat treated GagCAT VLP only inoculation induced a low response of $70 \mathrm{sfu} /$ $10^{6}$ splenocytes to the Gag CD4(13) peptide (Figure 3a). No response to the Gag CD8 peptide was induced by either VLP vaccine (Figure 3a). Both VLP preparations boosted a primary response to pTHGagC and the magnitudes of these responses were greater than the sum of the responses to the individual priming and boosting vaccines (Figure 3a). A cumulative response to the Gag CD8 and Gag CD4 peptides of $1225 \mathrm{sfu} / 10^{6}$ splenocytes in the IFN- $\gamma$ ELISPOT assay was measured when GagCAT VLPs were used as the boost while a cumulative response to these peptides of $1637 \mathrm{sfu} / 10^{6}$ splenocytes was measured when heated GagCAT VLPs were the boost vaccine. For the prime with pTHGagC and boost with either VLP preparation Gag CD8 T cells contributed approximately $600 \mathrm{sfu} / 10^{6}$ splenocytes to these cumulative responses (Figure 3a). The higher response achieved with the pTHGagC prime and heat treated GagCAT VLP boost as opposed to a GagCAT VLP boost was due to a greater frequency (2 fold) of responding Gag-specific CD4 T cells. These responses to a DNA prime and GagCAT VLP or heat-treated GagCAT VLP boost were of higher magnitude than two pTHGagC vaccinations which reached a cumulative response of $892 \mathrm{sfu} / 10^{6}$ splenocytes. The increase in response to two DNA vaccinations is due to an increase in responding Gag-specific IFN- $\gamma$ producing CD4 cells, without a boost of the Gag CD8 cells. In comparison for two DNA vaccinations CD4 T cells contribute $30 \%$ to the overall response while CD4 T cells contribute $46 \%$ and $66 \%$ to the overall response when the boost to a DNA prime is either GagCAT VLPs or heated GagCAT VLPs respectively (Figure 3a)

GagCAT VLP and heat-treated GagCAT VLP vaccinations also induced Gag CD4+ cells that produced IL-2 with cumulative CD4 T cell frequencies of $153 \mathrm{sfu} / 10^{6}$ splenocytes and $93 \mathrm{sfu} / 10^{6}$ splenocytes respectively (Figure $3 \mathrm{~b})$. The prime-boost vaccination regimens induced Gag CD8 and CD4 IL-2 producing T cells and the magnitude of these responses were greater than the sum of the responses to the individual priming and boosting vaccines (Figure $3 \mathrm{~b}$ ). The sum of IL-2 producing Gag CD8 and Gag CD4 T cells induced by pTHGagC were boosted by GagCAT VLPs and heat treated GagCAT VLPs to levels of $893 \mathrm{sfu} / 10^{6}$ splenocytes and $1387 \mathrm{sfu} /$ $10^{6}$ splenocytes respectively. CD8+ cells contributed similar frequencies of $310 \mathrm{sfu} / 10^{6}$ splenocytes to these total responses (Figure $3 \mathrm{~b}$ ). A pTHGag prime and hGagCAT VLP boost induced IL-2 producing CD4+ T cells of $1061 \mathrm{sfu} / 10^{6}$ splenocytes which is almost twice that induced by the pTHGagC prime and GagCAT VLP boost.

\section{Conclusions}

GagCAT VLPs that budded into the culture medium of $s f 21$ insect cells using the baculovirus expression system were pseudotyped with baculovirus Gp64 envelope glycoprotein. Electron microscopic examination of the GagCAT VLP preparation revealed that the cross-flow filtration technique used to isolate the VLPs from the culture supernatant successfully limited co-purification of baculovirus particles to very low levels. In addition CAT-encoding DNA carried by baculovirus particles in the GagCAT VLP preparation was not detected by CAT-specific PCR of the VLPs, which further supported very low baculovirus contamination (Figure $1 \mathrm{~g}$ ).

Although Gp64 pseudotyping has been documented [76], we now report that the Gp64 content of baculovirus-produced VLPs is very high relative to Gp120 on HIV particles ( 383 ng Gp64 per $1 \mu \mathrm{g} \mathrm{Gag})$. HIV VLPs of 120 to $150 \mathrm{~nm}$ in diameter are estimated to contain 
a)

\section{IFN-y ELISPOT responses}

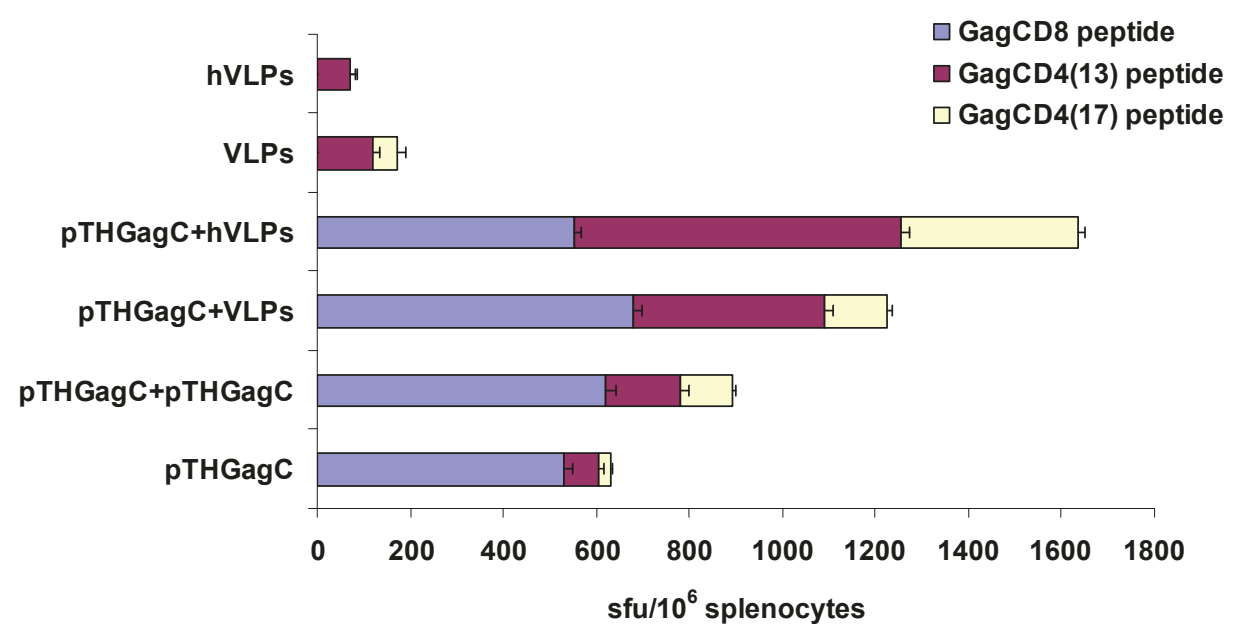

b)

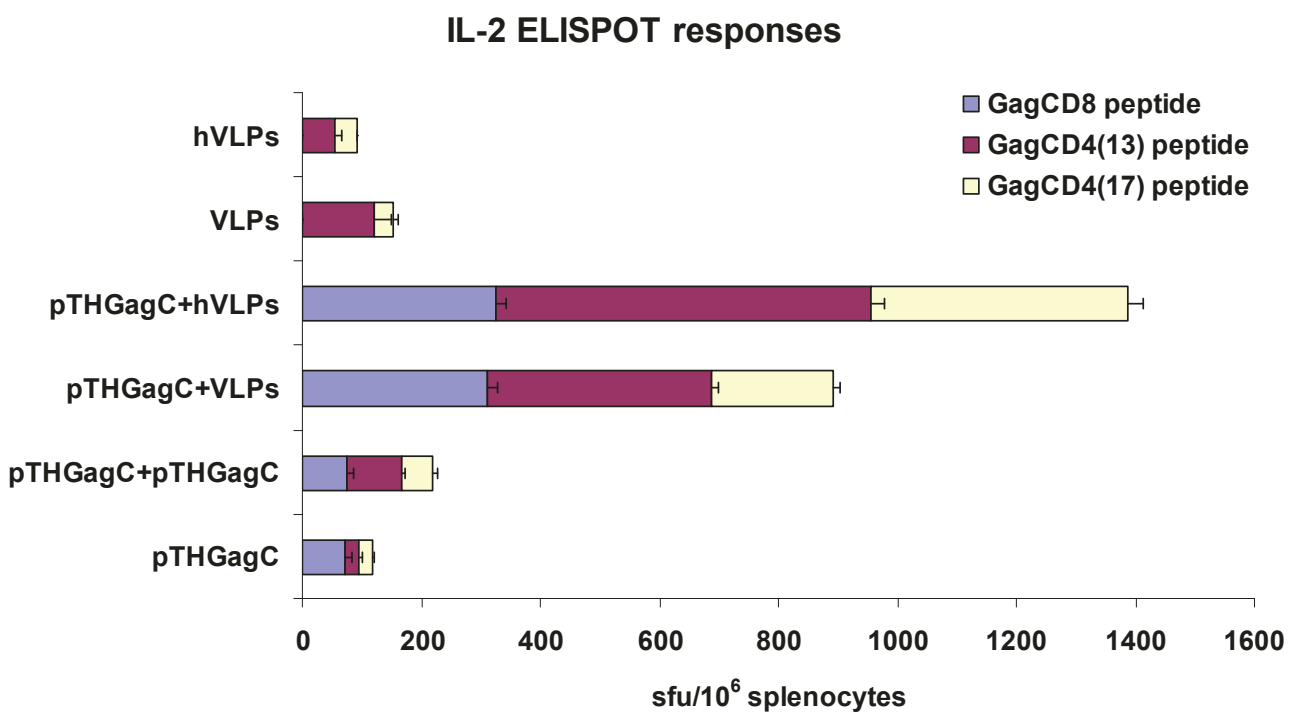

Figure 3 Immune responses in mice vaccinated with GagCAT VLPs. IFN- $\gamma$ (A) and IL-2 (B) ELISPOT responses of groups of BALB/c mice to Gag CD8 and Gag CD4 peptides on day 12 after vaccination with GagCAT VLPs (VLP) or heated GagCAT VLPs (hVLP) or pTHGagC and on day 40 for mice primed with pTHgagC then boosted on day 28 with VLPs or hVLPs. Splenocytes prepared from spleens combined from five mice per group were used in IFN- $\gamma$ or IL-2 ELISPOT assays with the indicated Gag peptides. Bars are the mean number of spots of triplicate reactions for $10^{6}$ splenocytes with indicated standard deviation of the mean. Data is that from one of three replicate experiments.

$\sim 5000$ Gag proteins [77]. Thus each VLP contains 1600 Gp64 molecules, or approximately 1 Gp64 molecule for every $3 \mathrm{Gag}$ molecules in each VLP. The number of glycoprotein envelope spikes on infectious HIV virions was originally estimated to be approximately 72 [78], while more recent studies have indicated this number to be 2 to 14 trimers [78-81], which is sufficient to mediate specific CD4+ T-cell entry. The far greater number of baculovirus Gp64 molecules found on baculovirus-produced VLPs means these could very probably mediate a baculovirus-specific mode and specificity of cellular entry.

Previous research has shown that HIV particles that lack envelope glycoproteins are most likely to be degraded in 
endocytic vesicles $[39,41]$, indicating that the entry and successful replication of HIV in mammalian cells is facilitated by the presence of glycoproteins on the outer surface of the viral particle. The Gp64 pseudotyped GagCAT VLPs containing a known quantity of encapsidated CAT RNA were thus assayed in our uptake experiments using BHK-21, HEK 293 and HeLa cells which are known to be permissive to Gp64-mediated recombinant baculovirus entry [54-56,58,60,61,74]. GagCAT VLPs were assumed to be taken up by these cell lines as the encapsidated CAT reporter RNA was successfully translated to produce CAT protein. The CAT protein levels yielded were similar irrespective of the type of cell in which they were produced. The encapsidated CAT RNA in our VLPs is representative of other RNAs that are normally present in the VLP expression system. To our knowledge, these results are the first to document the Gp64-mediated uptake of VLPs made using an insect cell expression system into mammalian cells, and the subsequent expression of a reporter RNA species encapsidated in the VLPs. Our results suggest that there is a strong possibility that RNA which is randomly encapsidated during VLP formation could be successfully translated into protein once it has been taken up by mammalian host cells. This finding contradicts previous assertions that baculovirus/insect cell-produced HIV-Gag VLPs are non-"infectious" [76].

The VLP heat inactivation experiments showed that heat treatment at $62^{\circ} \mathrm{C}$ reduced CAT protein levels in lysates of two of the cell types tested (BHK-21 and HeLa) to almost undetectable levels (Figure 2), which is in agreement with results obtained using live virus particles $[71,75]$. The application of heat to the VLPs was primarily to "disrupt" the particle surface structure: electron microscopic analysis of heat-treated VLPs showed that heat treatment did not noticeably disrupt or lyse the VLPs (Figure 1c). Heating of in vitro-transcribed CAT RNA prior to transfection also had no effect on CAT expression in the tested BHK-21 cell line (not shown). We concluded from this that the inhibition of CAT expression was most likely as a result of Gp64 damage on the GagCAT VLP surface. In the HEK 293 cells, CAT protein levels were relatively unaffected when higher levels of encapsidated RNA were used in the cell uptake assay. It is possible this is a result of the HEK293 cells employing an additional or alternate VLP cell uptake pathway to that used by the BHK-21 and HeLa cell lines. This variation in sensitivity to heat may be cause for concern considering that a mixed population of cell types may be present in the area of inoculation when used as a vaccine in mammalian subjects. UV irradiation of VLPs has also been tested in this laboratory, but this had little effect on abrogating or even decreasing GagCAT transcription and translation (data not shown).
With regard to particle immunogenicity, a literature review has suggested that pseudotyping Gag VLPs with functional/fusion competent envelope glycoproteins may be of paramount importance in stimulating both $\mathrm{MHC}-\mathrm{I}$ and MHC-I Gag processing pathways [11,82-85]. It has been shown that VLPs that did not display HIV-1 Env were unable to induce immune responses that were stronger than a DNA vaccine that produced soluble polypeptides [86]. In addition, HIV VLPs displaying HIVgp120 taken up by monocyte-derived dendritic cells (MDDC) [87] showed enhanced Th1- and Th2-cytokine production and were able to activate autologous naïve $\mathrm{CD}^{+}{ }^{+} \mathrm{T}$-cells and drive them towards a Th- 1 response [87]. Monkeys immunized with VSV-G pseudotyped SIV particles generated SIV-specific humoral and cellular immune responses, which significantly reduced peak viraemia levels of a challenge virus. In mice, VSV-G-pseudotyped HIV VLPs stimulated Gag-specific IgG and IgG1 antibody titres that were $\sim 100$ fold higher than nonpseudotyped VLPs. As a control, a fusion defective VSVG was also displayed on the HIV VLPs and was not able to enhance the VLP immune response. Insect cell-derived HIV/SIV-derived VLPs that have no specific mammalian virus-derived envelope glycoprotein have been found, nevertheless, to efficiently stimulate the MHC-1-driven CTL responses as well as humoral immune responses, which may be a result of the presence of the baculovirus Gp64 envelope glycoprotein [5,7,9,85,87-95].

The cellular immune response is partly dependent on the successful entry of viruses into the cytoplasm of the target cell resulting in viral replication rather than viral particle degradation which stimulates the Th1 immune response. This kind of entry would be facilitated by receptor-mediated Gp64 interactions. If heat treatment disrupts Gp64 on the Gag VLPs, successful entry of VLPs into the target cell would not occur, thus preventing a Th1 immune response to be stimulated. However, we showed that VLP heat inactivation did not appear to affect induction of subsequent immune responses (Figure 3). GagCAT VLPs both post-heating and unheated, induced low Gag-specific CD4 IFN- $\gamma$ and IL- 2 producing cells in mice and both VLPs preparations boosted immune responses induced by a primary DNA vaccine. It is not clear why a more substantial boost of the Gag-specific CD4 T cell response was observed with the hGagCAT VLPs. However, the VLP preparation only vaccinations and DNA vaccine prime VLP boost vaccination regimens induced magnitudes of Gag-specific immune responses as that induced by Gag VLPs [7,68].

In summary, BEVS-produced HIV-1 Gag VLPs were shown to be able to transfer and express foreign expression system-derived RNAs in mammalian cell lines. Transfection of mammalian cells with heat-treated VLPs 
did not prevent RNA expression in all cell lines, but reduced the range of cell lines that the VLPs could enter and thus the range of cells into which RNA was taken up. These results highlight the need to control the nucleic acid content of assembled Gag particles notwithstanding their need for random RNA encapsidation, crucial for particle assembly. A possible alternative to limit RNA encapsidation and hence transmission may lie with creating chimeric gag particles that do not require RNA for assembly, as has been shown by Crist et al., 2009 [96]. Chimeric Gag particles in which the nucleocapsid domain had been replaced with a trimerizing leucine zipper-domain showed an ability to assemble in 293Tcells, which released particles that lacked any detectable RNA. Future studies should investigate the feasibility of producing these chimeric particles in insect cell lines and assess their immunogenicity. Furthermore, where RNA transmission is evident, the RNA uptake pathways should be verified through the use of specific cell pathway uptake inhibitors or antibodies specific for functional receptors on the virion surface, such as Gp64.

\section{Acknowledgements}

This research was supported by The South African AIDS Vaccine Initiative (SAAVI). We thank Dr Carolyn Williamson for providing gag, from isolate Du422, Dr Mohamed Jaffer and the UCT EMU for assistance with electron microscopy and Shireen Galant, Desiree Bowers, Zaahier Isaacs and Anke Binder for their contributions to the immunology studies. The polyclonal antiserum ARP432 (donated by G. Reid) and HIV-1 protein standard (ARP695.2) were provided by the EU Programme EVA Centralised Facility for AIDS Reagents, NIBSC, UK (AVIP Contract Number LSHP-CT-2004-503487).

\section{Author details \\ 'Department of Molecular and Cell Biology, Faculty of Science, University of Cape Town, University Ave, Rondebosch 7701, South Africa. ${ }^{2}$ Institute of Infectious Diseases and Molecular Medicine, Faculty of Health Sciences, University of Cape Town, Anzio Rd, Observatory 7925, South Africa. ${ }^{3}$ Medical Research Council (South Africa), Tygerberg 7505, South Africa. ${ }^{4}$ Department of Medicine, Faculty of Health Sciences, University of Cape Town, Anzio Rd, Observatory 7925 , South Africa. ${ }^{5}$ National Health Laboratory Service, Groote Schuur Hospital, Main Rd, Observatory 7925, South Africa.}

\section{Authors' contributions}

ZV-O produced and characterised the VLPS, carried out the PCR and RT-PCR and tested expression of the RNA in cell lines and drafted the manuscript. ES and her group were responsible for carrying out the mouse experiments and performing the ELISPOT assays. AM and EPR were involved in supervision of the work, critically revising the manuscript for important intellectual content, and together with A-LW, conceived of the study, and participated in its design and coordination. All authors read and approved the final manuscript.

\section{Competing interests}

The authors declare that they have no competing interests.

Received: 26 April 2011 Accepted: 6 October 2011

Published: 6 October 2011

\section{References}

1. Aires KA, Cianciarullo AM, Carneiro SM, Villa LL, Boccardo E, PerezMartinez G, Perez-Arellano I, Oliveira ML, Ho PL: Production of human papillomavirus type $16 \mathrm{~L} 1$ virus-like particles by recombinant Lactobacillus casei cells. Appl Environ Microbiol 2006, 72:745-752.
2. Garland SM, Hernandez-Avila M, Wheeler CM, Perez G, Harper DM, Leodolter S, Tang GW, Ferris DG, Steben M, Bryan J, Taddeo FJ, Railkar R, Esser MT, Sings HL, Nelson M, Boslego J, Sattler C, Barr E, Koutsky LA: Quadrivalent vaccine against human papillomavirus to prevent anogenital diseases. N Engl J Med 2007, 356:1928-1943.

3. Paavonen J, Jenkins D, Bosch FX, Naud P, Salmeron J, Wheeler CM, Chow SN, Apter DL, Kitchener HC, Castellsague X, de Carvalho NS, Skinner SR, Harper DM, Hedrick JA, Jaisamrarn U, Limson GA, Dionne M, Quint W, Spiessens B, Peeters P, Struyf F, Wieting SL, Lehtinen MO, Dubin G: Efficacy of a prophylactic adjuvanted bivalent L1 virus-like-particle vaccine against infection with human papillomavirus types 16 and 18 in young women: an interim analysis of a phase III double-blind, randomised controlled trial. Lancet 2007, 369:2161-2170.

4. Buonaguro L, Visciano ML, Tornesello ML, Tagliamonte M, Biryahwaho B, Buonaguro FM: Induction of systemic and mucosal cross-clade neutralizing antibodies in BALB/c mice immunized with human immunodeficiency virus type 1 clade A virus-like particles administered by different routes of inoculation. J Virol 2005, 79:7059-7067.

5. Deml L, Schirmbeck R, Reimann J, Wolf H, Wagner R: Recombinant human immunodeficiency Pr55gag virus-like particles presenting chimeric envelope glycoproteins induce cytotoxic T-cells and neutralizing antibodies. Virology 1997, 235:26-39.

6. Imaoka K, Miller CJ, Kubota M, McChesney MB, Lohman B, Yamamoto M, Fujihashi K, Someya K, Honda M, McGhee JR, Kiyono H: Nasal immunization of nonhuman primates with simian immunodeficiency virus $p 55 \mathrm{gag}$ and cholera toxin adjuvant induces Th1/Th2 help for virusspecific immune responses in reproductive tissues. J Immunol 1998, 161:5952-5958.

7. Jaffray A, Shephard E, van HJ, Williamson C, Williamson AL, Rybicki EP: Human immunodeficiency virus type 1 subtype $C$ Gag virus-like particle boost substantially improves the immune response to a subtype $C$ gag DNA vaccine in mice. J Gen Virol 2004, 85:409-413.

8. Montefiori DC, Safrit JT, Lydy SL, Barry AP, Bilska M, Vo HT, Klein M, Tartaglia J, Robinson HL, Rovinski B: Induction of neutralizing antibodies and gag-specific cellular immune responses to an R5 primary isolate of human immunodeficiency virus type 1 in rhesus macaques. J Virol 2001, 75:5879-5890

9. Paliard X, Liu Y, Wagner R, Wolf H, Baenziger J, Walker CM: Priming of strong, broad, and long-lived HIV type 1 p55gag-specific CD8+ cytotoxic $T$ cells after administration of a virus-like particle vaccine in rhesus macaques. AIDS Res Hum Retroviruses 2000, 16:273-282.

10. Tsunetsugu-Yokota Y, Morikawa Y, Isogai M, Kawana-Tachikawa A, Odawara T, Nakamura T, Grassi F, Autran B, Iwamoto A: Yeast-derived human immunodeficiency virus type 1 p55(gag) virus-like particles activate dendritic cells (DCs) and induce perforin expression in Gag-specific CD8(+) T cells by cross-presentation of DCs. J Virol 2003, 77:10250-10259.

11. Wang S, Kennedy JS, West K, Montefiori DC, Coley S, Lawrence J, Shen S, Green S, Rothman AL, Ennis FA, Arthos J, Pal R, Markham P, Lu S: Crosssubtype antibody and cellular immune responses induced by a polyvalent DNA prime-protein boost HIV-1 vaccine in healthy human volunteers. Vaccine 2008, 26:1098-1110.

12. Aldovini A, Young RA: Mutations of RNA and protein sequences involved in human immunodeficiency virus type 1 packaging result in production of noninfectious virus. J Virol 1990, 64:1920-1926.

13. Berkowitz R, Fisher J, Goff SP: RNA packaging. Curr Top Microbiol Immunol 1996, 214:177-218

14. Berkowitz RD, Ohagen A, Hoglund S, Goff SP: Retroviral nucleocapsid domains mediate the specific recognition of genomic viral RNAs by chimeric Gag polyproteins during RNA packaging in vivo. J Virol 1995, 69:6445-6456.

15. Dannull J, Surovoy A, Jung G, Moelling K: Specific binding of HIV-1 nucleocapsid protein to PSI RNA in vitro requires $\mathrm{N}$-terminal zinc finger and flanking basic amino acid residues. EMBO J 1994, 13:1525-1533.

16. Gorelick RJ, Chabot DJ, Rein A, Henderson LE, Arthur LO: The two zinc fingers in the human immunodeficiency virus type 1 nucleocapsid protein are not functionally equivalent. J Virol 1993, 67:4027-4036.

17. Zhang $Y$, Barklis E: Nucleocapsid protein effects on the specificity of retrovirus RNA encapsidation. J Virol 1995, 69:5716-5722.

18. Alfadhli A, Dhenub TC, Still A, Barklis E: Analysis of human immunodeficiency virus type $1 \mathrm{Gag}$ dimerization-induced assembly. J Virol 2005, 79:14498-14506. 
19. Cimarelli A, Sandin S, Hoglund S, Luban J: Basic residues in human immunodeficiency virus type 1 nucleocapsid promote virion assembly via interaction with RNA. J Virol 2000, 74:3046-3057.

20. Clavel F, Orenstein JM: A mutant of human immunodeficiency virus with reduced RNA packaging and abnormal particle morphology. J Virol 1990, 64:5230-5234.

21. Muriaux D, Mirro J, Harvin D, Rein A: RNA is a structural element in retrovirus particles. Proc Natl Acad Sci USA 2001, 98:5246-5251.

22. Muriaux D, Mirro J, Nagashima K, Harvin D, Rein A: Murine leukemia virus nucleocapsid mutant particles lacking viral RNA encapsidate ribosomes. J Virol 2002, 76:11405-11413.

23. Ott DE, Coren LV, Gagliardi TD: Redundant roles for nucleocapsid and matrix RNA-binding sequences in human immunodeficiency virus type 1 assembly. J Virol 2005, 79:13839-13847.

24. Darlix JL, Lapadat-Tapolsky M, de RH, Roques BP: First glimpses at structure-function relationships of the nucleocapsid protein of retroviruses. J Mol Biol 1995, 254:523-537.

25. Poon DT, Wu J, Aldovini A: Charged amino acid residues of human immunodeficiency virus type 1 nucleocapsid $\mathrm{p} 7$ protein involved in RNA packaging and infectivity. J Virol 1996, 70:6607-6616.

26. Prats AC, Housset V, de BG, Cornille F, Prats H, Roques B, Darlix JL: Viral RNA annealing activities of the nucleocapsid protein of Moloney murine leukemia virus are zinc independent. Nucleic Acids Res 1991, 19:3533-3541.

27. Schmalzbauer E, Strack B, Dannull J, Guehmann S, Moelling K: Mutations of basic amino acids of NCp7 of human immunodeficiency virus type 1 affect RNA binding in vitro. J Virol 1996, 70:771-777.

28. Chang CY, Chang YF, Wang SM, Tseng YT, Huang KJ, Wang CT: HIV-1 matrix protein repositioning in nucleocapsid region fails to confer viruslike particle assembly. Virology 2008, 378:97-104.

29. Burniston MT, Cimarelli A, Colgan J, Curtis SP, Luban J: Human immunodeficiency virus type $1 \mathrm{Gag}$ polyprotein multimerization requires the nucleocapsid domain and RNA and is promoted by the capsiddimer interface and the basic region of matrix protein. J Virol 1999, 73:8527-8540.

30. Campbell S, Vogt VM: In vitro assembly of virus-like particles with Rous sarcoma virus Gag deletion mutants: identification of the p10 domain as a morphological determinant in the formation of spherical particles. J Virol 1997, 71:4425-4435.

31. Campbell S, Rein A: In vitro assembly properties of human immunodeficiency virus type $1 \mathrm{Gag}$ protein lacking the p6 domain. J Virol 1999, 73:2270-2279.

32. Wang SW, Aldovini A: RNA incorporation is critical for retroviral particle integrity after cell membrane assembly of Gag complexes. J Virol 2002, 76:11853-11865.

33. Zuber G, McDermott J, Karanjia S, Zhao W, Schmid MF, Barklis E: Assembly of retrovirus capsid-nucleocapsid proteins in the presence of membranes or RNA. J Virol 2000, 74:7431-7441.

34. Dimitrov AS, Xiao X, Dimitrov DS, Blumenthal R: Early intermediates in HIV1 envelope glycoprotein-mediated fusion triggered by CD4 and coreceptor complexes. J Biol Chem 2001, 276:30335-30341.

35. Stein BS, Gowda SD, Lifson JD, Penhallow RC, Bensch KG, Engleman EG: $\mathrm{pH}$-independent HIV entry into CD4-positive T cells via virus envelope fusion to the plasma membrane. Cell 1987, 49:659-668.

36. Fackler OT, Peterlin BM: Endocytic entry of HIV-1. Curr Biol 2000, 10:1005-1008.

37. Fredericksen BL, Wei BL, Yao J, Luo T, Garcia JV: Inhibition of endosomal/ lysosomal degradation increases the infectivity of human immunodeficiency virus. J Virol 2002, 76:11440-11446.

38. Marechal V, Clavel F, Heard JM, Schwartz O: Cytosolic Gag p24 as an index of productive entry of human immunodeficiency virus type 1. J Virol 1998, 72:2208-2212

39. Marechal V, Prevost MC, Petit C, Perret E, Heard JM, Schwartz O: Human immunodeficiency virus type 1 entry into macrophages mediated by macropinocytosis. J Virol 2001, 75:11166-11177.

40. Pauza CD, Price TM: Human immunodeficiency virus infection of $T$ cells and monocytes proceeds via receptor-mediated endocytosis. J Cell Biol 1988, 107:959-968.

41. Schaeffer E, Soros VB, Greene WC: Compensatory link between fusion and endocytosis of human immunodeficiency virus type 1 in human CD4 T lymphocytes. J Virol 2004, 78:1375-1383.
42. O'Reilly DRMLKLVA: Baculovirus expression vectors - A Laboratory manual. 2009

43. Oomens AG, Blissard GW: Requirement for GP64 to drive efficient budding of Autographa californica multicapsid nucleopolyhedrovirus. Virology 1999, 254:297-314

44. Blissard GW, Wenz JR: Baculovirus gp64 envelope glycoprotein is sufficient to mediate pH-dependent membrane fusion. J Virol 1992, 66:6829-6835.

45. Blissard GW: Baculovirus-insect cell interactions. Cytotechnology 1996, 20:73-93.

46. Hefferon KL, Oomens AG, Monsma SA, Finnerty CM, Blissard GW: Host cell receptor binding by baculovirus GP64 and kinetics of virion entry. Virology 1999, 258:455-468.

47. Kingsley DH, Behbahani A, Rashtian A, Blissard GW, Zimmerberg J: A discrete stage of baculovirus GP64-mediated membrane fusion. Mol Biol Cell 1999, 10:4191-4200.

48. Leikina $\mathrm{E}$, Onaran $\mathrm{HO}$, Zimmerberg J: Acidic $\mathrm{pH}$ induces fusion of cells infected with baculovirus to form syncytia. FEBS Lett 1992, 304:221-224

49. Long G, Pan X, Kormelink R, Vlak JM: Functional entry of baculovirus into insect and mammalian cells is dependent on clathrin-mediated endocytosis. J Virol 2006, 80:8830-8833.

50. Markovic I, Pulyaeva H, Sokoloff A, Chernomordik LV: Membrane fusion mediated by baculovirus gp64 involves assembly of stable gp64 trimers into multiprotein aggregates. J Cell Biol 1998, 143:1155-1166.

51. Monsma SA, Blissard GW: Identification of a membrane fusion domain and an oligomerization domain in the baculovirus GP64 envelope fusion protein. J Virol 1995, 69:2583-2595.

52. Monsma SA, Oomens AG, Blissard GW: The GP64 envelope fusion protein is an essential baculovirus protein required for cell-to-cell transmission of infection. J Virol 1996, 70:4607-4616.

53. Plonsky I, Cho MS, Oomens AG, Blissard G, Zimmerberg J: An analysis of the role of the target membrane on the Gp64-induced fusion pore. Virology 1999, 253:65-76.

54. Abe T, Takahashi H, Hamazaki H, Miyano-Kurosaki N, Matsuura Y, Takaku H: Baculovirus induces an innate immune response and confers protection from lethal influenza virus infection in mice. J Immunol 2003 171:1133-1139.

55. Airenne $\mathrm{KJ}$, Hiltunen $\mathrm{MO}$, Turunen MP, Turunen AM, Laitinen $\mathrm{OH}$ Kulomaa MS, Yla-Herttuala S: Baculovirus-mediated periadventitial gene transfer to rabbit carotid artery. Gene Ther 2000, 7:1499-1504.

56. Boyce FM, Bucher NL: Baculovirus-mediated gene transfer into mammalian cells. Proc Natl Acad Sci USA 1996, 93:2348-2352.

57. Condreay JP, Witherspoon SM, Clay WC, Kost TA: Transient and stable gene expression in mammalian cells transduced with a recombinant baculovirus vector. Proc Natl Acad Sci USA 1999, 96:127-132.

58. Gao H, Wang Y, Li N, Peng WP, Sun Y, Tong GZ, Qiu HJ: Efficient gene delivery into mammalian cells mediated by a recombinant baculovirus containing a whispovirus ie1 promoter, a novel shuttle promoter between insect cells and mammalian cells. J Biotechnol 2007, 131:138-143.

59. Hofmann C, Sandig V, Jennings G, Rudolph M, Schlag P, Strauss M: Efficient gene transfer into human hepatocytes by baculovirus vectors. Proc Natl Acad Sci USA 1995, 92:10099-10103.

60. Pieroni L, Maione $\mathrm{D}$, La MN: In vivo gene transfer in mouse skeletal muscle mediated by baculovirus vectors. Hum Gene Ther 2001, 12:871-881.

61. Shoji I, Aizaki H, Tani H, Ishii K, Chiba T, Saito I, Miyamura T, Matsuura Y: Efficient gene transfer into various mammalian cells, including nonhepatic cells, by baculovirus vectors. J Gen Virol 1997, 78(Pt 10):2657-2664.

62. Kumar M, Bradow BP, Zimmerberg J: Large-scale production of pseudotyped lentiviral vectors using baculovirus GP64. Hum Gene Ther 2003, 14:67-77.

63. Schauber CA, Tuerk MJ, Pacheco CD, Escarpe PA, Veres G: Lentiviral vectors pseudotyped with baculovirus gp64 efficiently transduce mouse cells in vivo and show tropism restriction against hematopoietic cell types in vitro. Gene Ther 2004, 11:266-275

64. Sinn PL, Burnight ER, Hickey MA, Blissard GW, McCray PB Jr: Persistent gene expression in mouse nasal epithelia following feline immunodeficiency virus-based vector gene transfer. J Virol 2005, 79:12818-12827.

65. van Harmelen JH, Shephard E, Thomas R, Hanke T, Williamson AL, Williamson C: Construction and characterisation of a candidate HIV-1 subtype C DNA vaccine for South Africa. Vaccine 2003, 21:4380-4389. 
66. Williamson C, Morris L, Maughan MF, Ping LH, Dryga SA, Thomas R, Reap EA, Cilliers T, van HJ, Pascual A, Ramjee G, Gray G, Johnston R, Karim SA, Swanstrom R: Characterization and selection of HIV-1 subtype $C$ isolates for use in vaccine development. AIDS Res Hum Retroviruses 2003, 19:133-144.

67. Halsey RJ, Tanzer FL, Meyers A, Pillay S, Lynch A, Shephard E, Williamson AL, Rybicki EP: Chimaeric HIV-1 subtype C Gag molecules with large in-frame C-terminal polypeptide fusions form virus-like particles. Virus Res 2008, 133:259-268.

68. Lynch AG, Tanzer F, Fraser MJ, Shephard EG, Williamson AL, Rybicki EP: Use of the piggyBac transposon to create HIV-1 gag transgenic insect cell lines for continuous VLP production. BMC Biotechnol 2010, 10(30):30.

69. Pillay S, Meyers A, Williamson AL, Rybicki EP: Optimization of chimeric HIV1 virus-like particle production in a baculovirus-insect cell expression system. Biotechnol Prog 2009, 25:1153-1160.

70. Pillay S, Shephard EG, Meyers AE, Williamson AL, Rybicki EP: HIV-1 sub-type $\mathrm{C}$ chimaeric VLPs boost cellular immune responses in mice. J Immune Based Ther Vaccines 2010, 8:7, \%19.

71. Poon B, Hsu JF, Gudeman V, Chen IS, Grovit-Ferbas K: Formaldehydetreated, heat-inactivated virions with increased human immunodeficiency virus type 1 env can be used to induce high-titer neutralizing antibody responses. J Virol 2005, 79:10210-10217.

72. Burgers WA, Shephard E, Monroe JE, Greenhalgh T, Binder A, Hurter E, van Harmelen JH, Williamson C, Williamson AL: Construction, characterization, and immunogenicity of a multigene modified vaccinia Ankara (MVA) vaccine based on HIV type 1 subtype C. AIDS Res Hum Retroviruses 2008, 24:195-206.

73. Shephard E, Burgers WA, van Harmelen JH, Monroe JE, Greenhalgh T, Williamson C, Williamson AL: A multigene HIV type 1 subtype $\mathrm{C}$ modified vaccinia Ankara (MVA) vaccine efficiently boosts immune responses to a DNA vaccine in mice. AIDS Res Hum Retroviruses 2008, 24:207-217.

74. Duisit G, Saleun S, Douthe S, Barsoum J, Chadeuf G, Moullier P: Baculovirus vector requires electrostatic interactions including heparan sulfate for efficient gene transfer in mammalian cells. J Gene Med 1999, 1:93-102.

75. Poon B, Safrit JT, McClure H, Kitchen C, Hsu JF, Gudeman V, Petropoulos C, Wrin T, Chen IS, Grovit-Ferbas K: Induction of humoral immune responses following vaccination with envelope-containing, formaldehyde-treated, thermally inactivated human immunodeficiency virus type 1. J Virol 2005, 79:4927-4935.

76. Ludwig C, Wagner R: Virus-like particles-universal molecular toolboxes Curr Opin Biotechnol 2007, 18:537-545.

77. Briggs JA, Simon MN, Gross I, Krausslich HG, Fuller SD, Vogt VM, Johnson MC: The stoichiometry of Gag protein in HIV-1. Nat Struct Mol Biol 2004, 11:672-675.

78. Gelderblom HR: Assembly and morphology of HIV: potential effect of structure on viral function. AIDS 1991, 5:617-637.

79. Chertova E, Bess JJ Jr, Crise BJ, Sowder II RC, Schaden TM, Hilburn JM Hoxie JA, Benveniste RE, Lifson JD, Henderson LE, Arthur LO: Envelope glycoprotein incorporation, not shedding of surface envelope glycoprotein (gp120/SU), Is the primary determinant of SU content of purified human immunodeficiency virus type 1 and simian immunodeficiency virus. J Virol 2002, 76:5315-5325.

80. Zhu P, Chertova E, Bess J Jr, Lifson JD, Arthur LO, Liu J, Taylor KA, Roux KH: Electron tomography analysis of envelope glycoprotein trimers on HIV and simian immunodeficiency virus virions. Proc Natl Acad Sci USA 2003, 100:15812-15817.

81. Zhu P, Liu J, Bess J Jr, Chertova E, Lifson JD, Grise H, Ofek GA, Taylor KA, Roux $\mathrm{KH}$ : Distribution and three-dimensional structure of AIDS virus envelope spikes. Nature 2006, 441:847-852.

82. Bellier B, Dalba C, Clerc B, Desjardins D, Drury R, Cosset FL, Collins M, Klatzmann D: DNA vaccines encoding retrovirus-based virus-like particles induce efficient immune responses without adjuvant. Vaccine 2006, 24:2643-2655.

83. Granelli-Piperno A, Zhong L, Haslett P, Jacobson J, Steinman RM: Dendritic cells, infected with vesicular stomatitis virus-pseudotyped HIV-1, present viral antigens to CD4+ and CD8+ T cells from HIV-1-infected individuals. $\mathrm{J}$ Immunol 2000, 165:6620-6626.

84. Kuate $\mathrm{S}$, Stahl-Hennig C, Stoiber H, Nchinda G, Floto A, Franz M, Sauermann U, Bredl S, Deml L, Ignatius R, Norley S, Racz P, Tenner-Racz K, Steinman RM, Wagner R, Uberla K: Immunogenicity and efficacy of immunodeficiency virus-like particles pseudotyped with the $\mathrm{G}$ protein of vesicular stomatitis virus. Virology 2006, 351:133-144.

85. Marsac D, Loirat D, Petit C, Schwartz O, Michel ML: Enhanced Presentation of Major Histocompatibility Complex Class I-Restricted Human Immunodeficiency Virus Type 1 (HIV-1) Gag-Specific Epitopes after DNA Immunization with Vectors Coding for Vesicular Stomatitis Virus Glycoprotein- Pseudotyped HIV-1 Gag Particles. The Journal of Virology 2002, 76:7544-7553.

86. Wong SB, Siliciano RF: Contribution of virus-like particles to the immunogenicity of human immunodeficiency virus type 1 Gag-derived vaccines in mice. J Virol 2005, 79:1701-1712.

87. Buonaguro L, Tornesello ML, Tagliamonte M, Gallo RC, Wang LX, KaminLewis R, Abdelwahab S, Lewis GK, Buonaguro FM: Baculovirus-derived human immunodeficiency virus type 1 virus-like particles activate dendritic cells and induce ex vivo T-cell responses. J Virol 2006, 80:9134-9143.

88. Bachmann MF, Lutz MB, Layton GT, Harris SJ, Fehr T, Rescigno M, RicciardiCastagnoli P: Dendritic cells process exogenous viral proteins and viruslike particles for class I presentation to CD8+ cytotoxic T lymphocytes. Eur J Immunol 1996, 26:2595-2600.

89. Buonaguro L, Racioppi L, Tornesello ML, Arra C, Visciano ML, Biryahwaho B, Sempala SD, Giraldo G, Buonaguro FM: Induction of neutralizing antibodies and cytotoxic T lymphocytes in Balb/c mice immunized with virus-like particles presenting a gp120 molecule from a HIV-1 isolate of clade A. Antiviral Res 2002, 54:189-201.

90. Deml L, Speth C, Dierich MP, Wolf H, Wagner R: Recombinant HIV-1 Pr55gag virus-like particles: potent stimulators of innate and acquired immune responses. Mol Immunol 2005, 42:259-277.

91. Kuate S, Stahl-Hennig C, Stoiber H, Nchinda G, Floto A, Franz M, Sauermann U, Bredl S, Deml L, Ignatius R, Norley S, Racz P, Tenner-Racz K, Steinman RM, Wagner R, Uberla K: Immunogenicity and efficacy of immunodeficiency virus-like particles pseudotyped with the $\mathrm{G}$ protein of vesicular stomatitis virus. Virology 2006, 351:133-144.

92. Ruedl C, Storni T, Lechner F, Bachi T, Bachmann MF: Cross-presentation of virus-like particles by skin-derived CD8(-) dendritic cells: a dispensable role for TAP. Eur J Immunol 2002, 32:818-825.

93. Ruedl C, Schwarz K, Jegerlehner A, Storni T, Manolova V, Bachmann MF: Virus-like particles as carriers for T-cell epitopes: limited inhibition of Tcell priming by carrier-specific antibodies. J Virol 2005, 79:717-724.

94. Chege GK, Shephard EG, Meyers A, van HJ, Williamson C, Lynch A, Gray CM, Rybicki EP, Williamson AL: HIV-1 subtype C Pr55gag virus-like particle vaccine efficiently boosts baboons primed with a matched DNA vaccine. J Gen Virol 2008, 89:2214-2227.

95. Kirkegaard T, Wheatley A, Melchjorsen J, Bahrami S, Pedersen FS, Center RJ, Purcell DF, Ostergaard L, Duch M, Tolstrup M: Induction of humoral and cellular immune responses against the HIV-1 envelope protein using gamma-retroviral virus-like particles. Virol J 2011, 8:381.

96. Crist RM, Datta SA, Stephen AG, Soheilian F, Mirro J, Fisher RJ, Nagashima K, Rein A: Assembly properties of human immunodeficiency virus type 1 Gag-leucine zipper chimeras: implications for retrovirus assembly. J Virol 2009, 83:2216-2225.

doi:10.1186/1743-422X-8-462

Cite this article as: Valley-Omar et al:: Abrogation of contaminating RNA activity in HIV-1 Gag VLPs. Virology Journal 2011 8:462.

\section{Submit your next manuscript to BioMed Central and take full advantage of:}

- Convenient online submission

- Thorough peer review

- No space constraints or color figure charges

- Immediate publication on acceptance

- Inclusion in PubMed, CAS, Scopus and Google Scholar

- Research which is freely available for redistribution

Submit your manuscript at www.biomedcentral.com/submit
C Biomed Central 